\title{
Implementasi Metode Apriori pada Data Mining untuk Pola Pembelian Barang pada Toko Matahari Kota Lubuklinggau
}

\author{
Calvin Andrew Suwandi ${ }^{1}$, Robi Yanto ${ }^{2}$, Deni Apriadi ${ }^{3}$ \\ ${ }^{1,2}$ Sistem Informasi, STMIK Bina Nusantara Jaya Lubuklinggau \\ Jl Yos Sudarso No 97 A Kel Jawa Kanan Kota Lubuklinggau, Sumatera \\ SelatanE-mail : calvinandrewmatahari79@gmail.com, \\ wrtech30@gmail.com,denidrv@gmail.com
}

\begin{abstract}
In this activity, Matahari Shop carries out the process of buying and selling toys of various shapes and sizes. Sales transactions do not only occur once a day but can occur dozens of times so that the sales data that occur accumulate, so if allowed to be more and more, it will confuse the shop owner. With the progress of the times that make human work easier, the ability to collect and process data will be more advanced. The use of knowledge and a quality of information in the sales data transaction is known as data mining. Each transaction must have different data which is only used as a report to be given to the leadership but never used, the information should be read from the transaction data collected from year to year so that it can improve the layout position of a store's goods. In data mining, there must be a method to solve problems so the method chosen to solve the problem is the Apriori method. Data collection methods are inseparable in the construction of data mining in the form of observations, interviews, and literature studies. The method of developing the system is the waterfall. The design model uses DFD and ERD. System testing techniques use acceptance testing techniques. The technique of using the sample is using the Systematic Random Sampling method which takes 3 years starting from 2018-2020. The results of the research are the implementation of the priori method in data mining for the pattern of purchasing goods at Matahari Store Lubuklinggau City, the application is built with a programming language, namely PHP and uses the MySQL database to increase sales and facilitate the position of the layout between goods.
\end{abstract}

Keywords: Paper sheets, Data Mining, Purchase Patterns of Goods

\begin{abstract}
Abstrak
Pada kegiatanya Toko Matahari ini melakukan proses jual beli mainan dengan berbagai macam bentuk dan ukuran. Transaksi Penjualan tidak hanya terjadi sekali dalam setiap hari tetapi bisa terjadi puluhan kali sehingga data penjualan yang terjadi menumpuk maka jika dibiarkan akan semakin banyak, maka akam membuat pemilik toko menjadi bingung. Dengan kemajuan zaman yang membuat pekerjaan manusia semakin mudah, maka semakin maju pula kemampuan mengumpulkan dan mengolah data. Pemanfaatan suatu pengetahuan dan suatu kualitas informasi dalam transaksi data penjualan tersebut sehingga disebut sebagai data mining. Setiap transaksi pasti memiliki data-data yang berbeda yang hanya dijadikan suatu laporan untuk diberikan ke pimpinan tetapi tidak pernah dimanfaatkan, seharusnya data transaksi yang dikumpulkan dari tahun ke tahun tersebut dibaca informasinya sehingga dapat memperbaiki posisi tata letak barang suatu toko. Dalam data mining pasti memiliki metode untuk menyelesaikan masalah sehingga metode yang dipilih untuk menyelesaikan masalah yaitu metode Apriori. Metode pengumpulan data merupakan hal yang tidak bisa dipisahkan dalam pembangunan data mining berupa observasi, wawancara, dan studi pustaka. Metode pengembangan sistemnya waterfall. Model perancangan menggunakan DFD dan ERD. Teknik pengujian sistem menggunakan teknik acceptance testing. Teknik penggunaan sampel yaitu menggunakan metode Systematic Random Sampling yang mengambil waktu sebanyak 3 tahun terhitung mulai dari 2018-2020. Hasil penelitian yaitu Implementasi Metode Apriori pada Data Mining untuk Pola Pembelian Barang pada Toko Matahari Kota Lubuklinggau, aplikasi dibangun dengan suatu bahasa pemrograman yaitu PHP dan menggunakan database MySQL dengan untuk pengembangan peningkatkan penjualan dan memudahkan posisi tata letak antar barang.
\end{abstract}

Kata Kunci: Lembaran kertas, Data Mining, Pola Pembelian Barang

\section{Pendahuluan}

Zaman yang sudah berkembang dengan sangat maju memungkinkan semua dilakukan secara cepat seperti pengumpulan dan dalam penyimpanan suatu data, memiliki memori yang dapat menampung dengan sangat banyak, dan harga yang murah. Kemajuan teknologi yang berkembang dengan sangat pesat menimbulkan suatu masalah yaitu data yang berlebihan, contoh: suatu data penjualan dan pembelian pada sebuah swalayan, data rekening pada bank, dan sebagainya. Suatu database memiliki batas tertentu sehingga 
tidak bisa sebuah sistem dipakai seumur hidup.. Masalah ini dapat terjadi karena pembelian perangkat lunak dan perangkat keras murah sehingga data yang ditampung tidak bisa melebihi kapitas yang ada tidak akan bisa tercapai. Informasi yang dapat diambil dalam suatu database susah untuk terpenuhi karena sistem tidak bisa menampung informasi dalam jumlah yang besar. Maka diperlukan, suatu sistem berupa data mining yang mampu menerapkan dan menyediakan suatu kualitas dalam informasi dari kegiatan yang dilaksanakan lalu diolah menjadi data yang masih mentah sehingga menjadi suatu informasi yang berguna.

Toko Matahari merupakan salah satu toko yang ada di Kota Lubuklinggau yang menjual berbagai macam jenis mainan anak-anak. Untuk membuat konsumen merasa puas maka Toko Matahari dapat menyediakan produk yang baik, konsumen merasa mudah untuk belanja dan memiliki pelayanan yang baik. Seiring meningkatnya persaingan, dibutuhkan strategi khusus untuk meningkatkan kepuasan konsumen dan meningkatkan penjualan. Pola belanja konsumen dapat dilihat dari bagaimana konsumen berbelanja sehingga pimpinan dapat meletakkan barang secara tidak sembarangan. Ketika konsumen merasa mudah dan nyaman dalam berbelanja maka pemilik toko berhasil untuk meletakkan barang dengan tepat. Dari hasil brainstorming dengan pihak manajemen Toko Matahari, pelanggan harus berkeliling mencari barang satu ke barang lainnya sesuai keinginan dan produk yang disusun masih menggunakan persepsi saja.

Data mining berupa suatu cara untuk mengolah teknik-teknik pembelajaran komputer dalam menyediakan kualitas berupa informasi tanpa manual [1]. Berikut merupakan macam-macam algoritma yang ada dalam suatu data mining berupa AIS Algorithm, Partition Algorithm, DHP Algorthm, dan Apriori Algorthm. Data mining sendiri memiliki beraneka ragam jenis algoritma yang ada untuk menyelesaikan suatu masalah. Dari berbagai macam algoritma yang ada dalam data mining ada satu algoritma yang sangat cocok untuk menyelesaikan tentang masalah tata letak suatu barang dalam toko yaitu Algoritma Apriori [2]. Algoritma apriori yaitu sebuah algoritma yang memiliki suatu fungsi untuk mengatur hubungan antar keterkaitan dalam atribut-atribut yang dipakai. Suatu sistem dapat bekerja dengan cara menganalisa dan menghasilkan polapola yang saling berelasi dengan barang-barang yang dijual. Teknik ini disebut 'barang satu dan barang yang lainnya' yang memiliki nama lain berupa analisis asosiasi atau association rule. Kesimpulan data mining yaitu dapat menjelaskan suatu kondisi, mengklarifikasi pernyataan dan harus dapat menemukan pola baru yang sebelumnya tidak ada sehingga memudahkan dalam menentukan posisi tata letak barang [3]. Pola pembelian barang yang sudah diolah dalam sistem memiliki fungsi untuk mempermudah keputusan seorang pembeli sehingga pembeli tidak perlu terlalu lama dalam menentukan barang apa dengan apa yang akan dibeli dan mempermudah juga bagi pihak penjual untuk melihat hasil dalam pola pembelian yang ada dalam sistem yang sudah dibuat sehingga didalam kurun waktu mendatang dapat ditarik suatu kesimpulan bagi penjual untuk menentukan mana barang yang laris dan mana barang yang kurang laris dan dari barang yang laris tadi maka pemilik toko dapat memesan barang mana saja yang laris dalam jumlah yang banyak.

Berdasarkan masalah yang dialami pada latar belakang, sehingga peneliti mengangkat judul "Implementasi Metode Apriori pada Data Mining untuk Pola Pembelian Barang pada Toko Matahari Kota Lubuklinggau".

Adapun tujuan dari penelitian ini adalah :

1) Untuk menerapkan metode Apriori pada pola pembelian barang pada Toko Matahari.

2) Untuk merancang dan membangun suatu sistem data mining pada Toko Matahari.

\section{Tinjauan Pustaka \\ 2.1. Data Mining}

Data mining yaitu suatu cara untuk mengolah teknik-teknik pembelajaran komputer untuk mengetahui dan menghasilkan suatu informasi secara cepat atau instan [1].

Data mining sendiri berupa suatu sistem penemuan pola yang bisa dikatakan bermanfaat karena dapat dimengerti dalam suatu database yang sangat besar sehingga dapat menampung data dengan banyak [4].

Jadi, data mining yaitu suatu cara untuk memperoleh informasi baru dari bermacam-macam informasi yang exist didalam suatu organisasi sehingga informasi baru yang dihasilkan dapat mempermudah mencari suatu jawaban. Data mining sendiri dapat dikatakan sebagai proses "menambang" pengetahuan dari berbagai macam informasi yang ada. Istilah yang berbeda untuk data mining adalah Knowlegde Discovery Database (KDD). Data mining yang dipakai yaitu suatu tahapan proses KDD [5] :

1) Data Selection mampu melakukan analisis sehingga munculnya suatu target dan fokus pada suatu sampel sehingga suatu data baru dapat ditemukan. Hasil dari data dibuat laporan yang dicetak dalam bentuk kertas.

2) Pre-processing / Cleaning berupa suatu cara yang dilakukan seperti penghapusan noise. Proses cleaning berupa menghapus data duplikat secara otomatis dan dapat memperbaiki secara otomatis data yang memiliki kesalahan yaitu salah cetak data.

3) Transformation merupakan proses loading atau menunggu data yang besar dalam mengeluarkan suatu hasil tentang barang yang cocok.

4) Suatu sistem harus memiliki proses KDD memiliki karakterisasi, asosiasi, regresi dan clustering. Proses KDD sangat bergantung pemilihan teknik suatu algoritma .

5) Interpretation/ Evaluation adalah data mining yang dihasilkan harus bisa diterjemahkan dalam bentuk suatu pola yang bisa dibaca. Seluruh hasil pola informasi harus dapat ditampilkan secara ringkas sehingga mudah dimengerti.

Data mining memiliki dua sifat berupa deskriptif dan prediktif. Data mining bersifat deskriptif yaitu data mining yang menjelaskan keseluruhan data sehingga dapat mencari pola mana yang paling dipahami. Kebalikannya data mining yang bersifat prediktif berupa data mining digunakan 
untuk melakukan prediksi dengan model pengetahuan yang ada. Kelompok-kelompok yang harus ada dalam data mining yaitu [6]:

1) Deskripsi : analis mendeskripsikan pola yang ada pada suatu data.

2) Estimasi : suatu cara yang serupa dengan kelompok klasifikasi tetapi hasil yang dihasilkan berupa numerik

3) Prediksi : sesuatu yang belum pernah terjadi di masa depan.

4) Klasifikasi : suatu cara yang serupa dengan kelompok estimasi tetapi hasil yang dihasilkan berupa kategorik

5) Clustering : merupakan suatu record yang saling berkelompok dalam suatu kelas yang sama maupun yang berbeda

6) Asosiasi : melakukan analisis pada kurun waktu yang bersamaan.

\subsection{Apriori}

Algoritma Apriori merupakan salah satu algoritma yang dapat digunakan untuk menyelesaikan masalah tentang penjualan dalam data mining. Analisis Apriori merupakan suatu asosiatif antara suatu hal yang saling berkaitan. Analisis asosiasi berupa sebuah patokan untuk mencari hasil yang dapat dijadikan sebagai sebuah patokan. Suatu algoritma apriori memiliki dua parameter, berupa support dan confidence. Confidence (nilai kepastian) berupa hubungan-hubungan yang saling berkaitan dalam data mining yang tidak bisa dipisahkan, sedangkan support (nilai penunjang) merupakan kombinasi yang ada dalam confdence dijadikan sebuah persentase. Untuk mencari Assosiation rule ada tahapan yang perlu dilakukan yaitu pertama yaitu melakukan analisis untuk mengumpulkan data, kedua berupa mencari frequent dalam itemset. Frequent itemset yaitu dalam apriori pasti memiliki banyak item-item yang muncul [7].

Frequent Itemset memiliki proses yang harus ilakukan dalam algoritma apriori berupa:

1) Join (penggabungan)

Proses penggabungan itu sendiri dapat dilakukan dengan cara penambahan item sehingga menghasilkan suatu kombinasi dalam itemset.

2) Prune (pemangkasan)

Proses pemangkasan merupakan hasil dari proses pertama yaitu join atau penggabungan kemudian dilakukan prune menggunakan minimal support yang ditentukan oleh pengguna [8].

Untuk menghitung support digunakan rumus :

Support $\mathrm{A}=\underline{\text { Jumlah transaksi mengandung } \mathrm{A}}$

Total transaksi

Sedangkan untuk memperoleh nilai support dari 2 item didapat dari rumus:

$$
\text { Support }(\mathrm{A}, \mathrm{B})=\frac{\Sigma \text { Transaksi Mengandung A dan B }}{\Sigma \text { Transaksi }}
$$

Pembentukkan aturan pada algoritma apriori setelah frekuensi tinggi ditemukan pada pola yang ada, kemudian mencari syarat minimum confidence dengan menghitung confidence aturan asosiasif "jika A maka B" untuk mencari aturan asosiasi. Untuk mencari nilai confidence dari aturan "Jika A maka B" menggunakan rumus:

$$
\text { Confidence } \mathrm{P}(\mathrm{B} \mid \mathrm{A})=\frac{\sum \text { Transaksi Mengandung A dan } \mathrm{B}}{\Sigma \text { Transaksi Mengandung A }}
$$

\subsection{Pola Pembelian Barang}

Pola adalah suatu benda yang dipisah menjadi beberapa bagian dari bentuk asli yang ada. Definisi Pembelian adalah suatu cara yang harus diperlukan oleh dua orang yang menukarkan barang atau jasa yang dimiliki dengan menggunakan suatu benda yang disebut uang dan sama-sama memiliki kesepakatan. Barang adalah cara menemukan suatu benda yang dapat dilihat secara fisik dan dapat disimpan [9].

Jadi, kesimpulan dari pengertian-pengertian di atas dapat diambil suatu pengertian yaitu pembelian merupakan hal yang tentunya dilakukan dalam kehidupan. Pembelian terjadi ketika dua pelaku yaitu seorang penjual dan seorang pembeli bertemu saling menguntungkan kedua belah pihak [10]. Untuk mengetahui tingkat pembelian, pemilik toko harus dapat memprediksi barang apa saja yang banyak dibeli oleh pembeli. Dalam hal ini ada keterkaitan antara pembelian dan pengertian dari algoritma apriori yang akan didapat dari data mining. Dalam data mining dengan memasukkan rumus dan mendapatkan hasil, penjual akan mengerti dan memahami apa saja kemungkinan barang yang akan laku di pasaran sehingga dapat membantu penjual di masa depan.

\section{Metodelogi Penelitian}

Adapun tahapan penelitian yang dilakukan dalam membangun data mining untuk pola pembelian barang menggunakan metode apriori pada Toko Matahari Lubuklinggau seperti pada gambar. 1 sebagai berikut

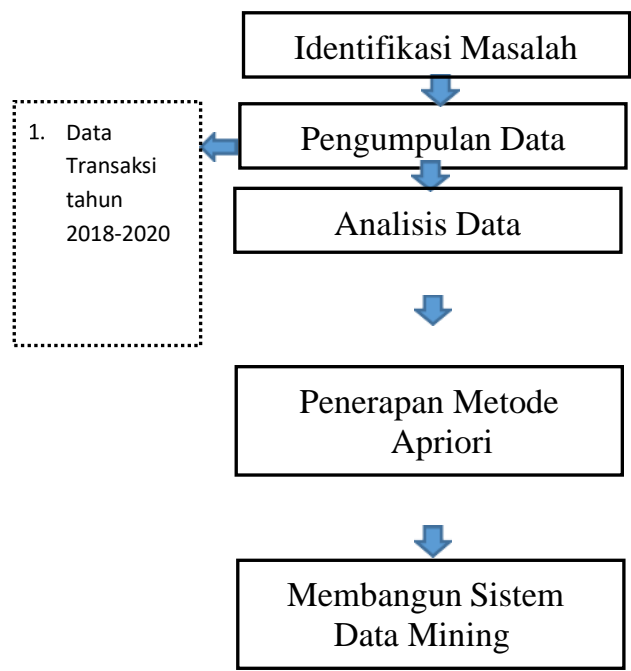




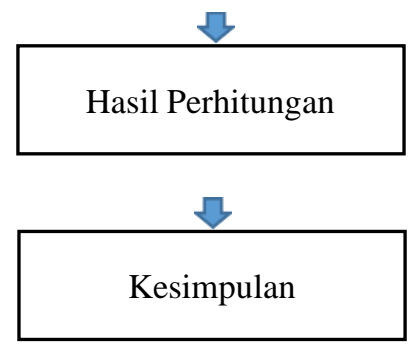

Gambar 1. Tahapan Penelitian

\section{Hasil dan Pembahasan}

\subsection{Analisis Sistem yang Berjalan}

Pada Toko Matahari Lubuklinggau melakukan transaksi penjualan namun barang yang sudah dijual biasanya ditulis dalam lembaran kertas. Pemilik toko menulis ulang barang yang sudah dijual secara manual ke kertas baru untuk mencatat laporan penjualan setiap bulan.

Dengan sistem yang berjalan saat ini, pemilik toko juga kesulitan untuk menentukan barang mana yang laku dan barang mana yang tidak laku. Selain itu, pelanggan berputarputar mengelilingi toko untuk mendapatkan barang yang dicari. Cara penyusunan suatu produk harus dilakukan dengan melihat catatan penjualan berupa barang apa yang laku kemarin dan diletakkan didepan begitu seterusnya. Pemanfaatan data transaksi yang ada belum dilakukan secara teratur karena peletakkan barang-barang yang ada pada toko dilakukan secara acak.

\subsection{Analisis Sistem yang Ditawarkan}

Berdasarkan analisis yang sedang berjalan penulis menawarkan sistem yaitu "Implementasi Metode Apriori pada Data Mining untuk Pola Pembelian Barang pada Toko Matahari Kota Lubuklinggau". Metode yang digunakan adalah Apriori. Pembangunan data mining ini menggunakan metode pengumpulan data yaitu observasi, wawancara, studi pustaka. Metode pengembangan sistemnya waterfall. Model perancangan menggunakan ERD dan DFD. Teknik pengujian sistem menggunakan acceptance testing. Teknik penggunaan sampel yaitu menggunakan metode Systematic Sampling secara acak. Data yang dipakai dari tahun 20182020. Adapun sistem tersebut dapat digunakan oleh dua user yaitu admin dan dari pimpinan itu sendiri.

Admin dapat mengakses sistem dengan menginputkan username dan password, apabila username dan password yang diinput benar, kemudian admin tersebut dapat masuk pada halaman utama admin, admin disini dapat melakukan input data barang, input minimal transaksi (support), input minimal confidence, input tanggal transaksi dan pimpinan dalam sistem ini cukup melihat hasil rule (hasil perhitungan). Sistem ini memiliki cara yang harus diterapkan dalam bekerja dengan cara menidentifikasi dan menghasilkan pola-pola yang saling berhubungan dengan barang-barang yang dijual. Teknik inilah merupakan nama lain dari teknik analisis asosiasi atau association rule dimana berhubungan tentang 'barang satu bersama barang lainnya'.

Dengan adanya sistem yang dipakai yang nantinya akan dibangun diharapkan dapat mempermudah pengguna berdasarkan kebutuhannya masing-masing baik dari admin dan dari pimpinan itu sendiri

\subsection{Data Flow Diagram (DFD) Level 0}

Perancangan Data Flow Diagram (DFD) level 0 Pada Aplikasi Data Mining Pola Pembelian Barang tertera pada gambar 2 dibawah ini:

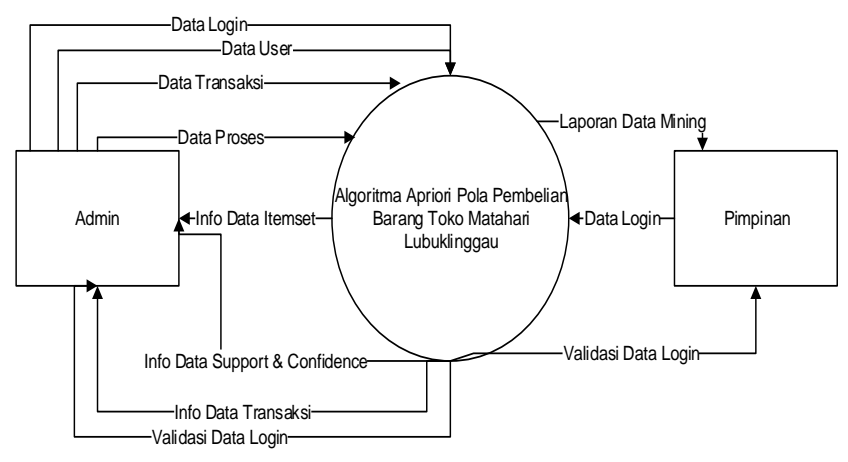

Gambar 2 Data Flow Diagram Level 0

\subsection{Data Flow Diagram (DFD) Level 1}

Perancangan Data Flow Diagram (DFD) level 1 Pada Aplikasi Data Mining Pola Pembelian Barang tertera pada gambar 3 dibawah ini:

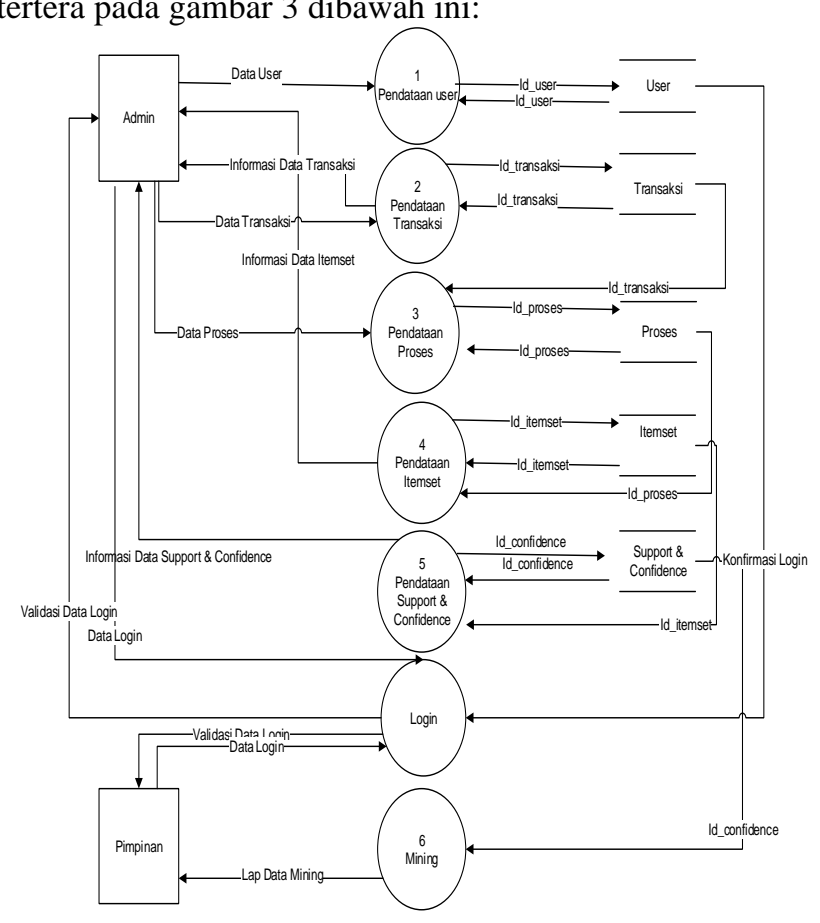

Gambar 3 Data Flow Diagram Level 1

\subsection{Entity Relationship Diagram (ERD)}

Entity Relationship Diagram (ERD) menggambarkan suatu diagram yang menunjukkan entitas yang digunakan dan relasinya. Entity Relationship Diargam (ERD) Aplikasi Data Mining Pola Pembelian Barang ini tertera pada gambar 4 . 


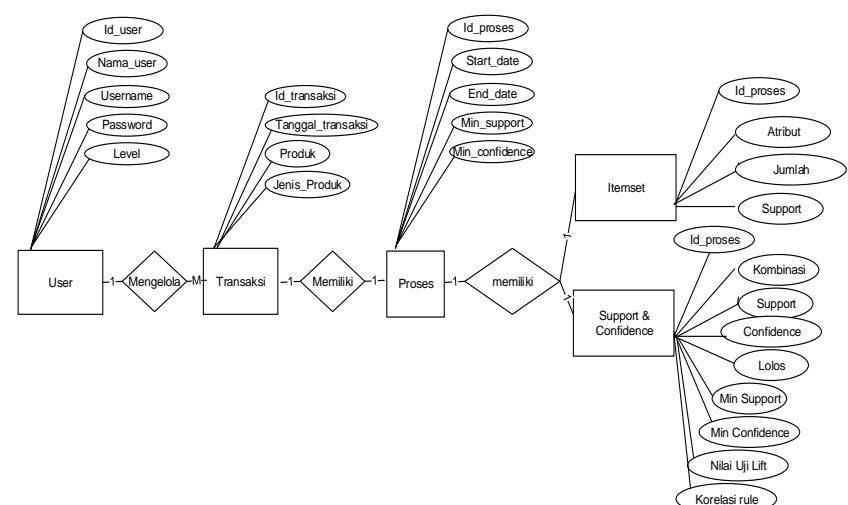

Gambar 4 Entity Relationship Diargam (ERD)

\subsection{Pembahasan}

\section{a. Halaman Login}

Pada saat kita akan membuka halaman admin, maka harus melakukan login terlebih dahulu. Halaman ini untuk memastikan bahwa yang berhak mengelola data adalah orang yang diizinkan atau yang memiliki akses, jika yang mengakses admin, maka admin dapat masuk ke sistem. Adapun halaman login tertera pada gambar dibawah ini

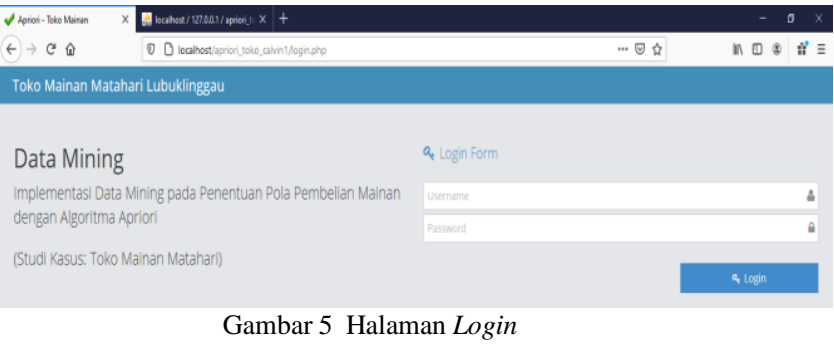

\section{b. Halaman Utama Admin}

Pada saat admin berhasil login menggunakan username dan password, maka admin akan berada dihalaman utama admin. Pada halaman utama admin tersebut terdapat beberapa menu yang dapat diakses oleh admin seperti halaman utama, user, data transaksi, proses apriori, hasil serta logout. Adapun halaman utama admin tertera seperti gambar dibawah ini :

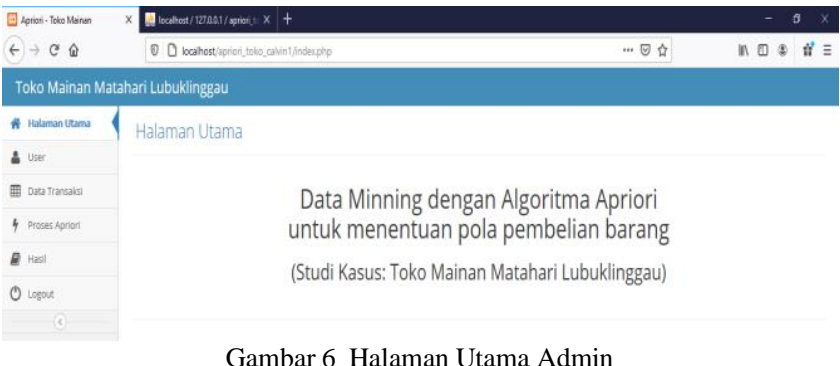

\section{c. Halaman Input Data User}

Admin dapat menginputkan nama, username, level, password dan konfirmasi password, pada halaman input data user juga dilengkapi dengan tombol simpan. Adapun halaman input data user tertera seperti gambar dibawah ini :

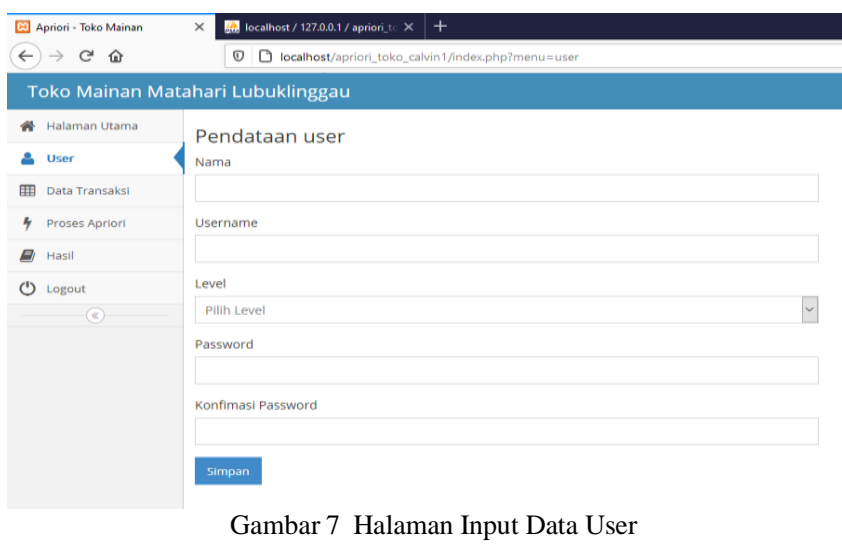

\section{d. Halaman Data User}

Pada halaman data user berisi data-data user yang telah di input sebelumnya. Data user dapat diolah seperti melakukan penghapusan data, pengeditan data, dan penambahan data. Pada sistem ini pengguna yang memiliki hak akses yaitu admin. Adapun halaman data user tertera seperti gambar dibawah ini :

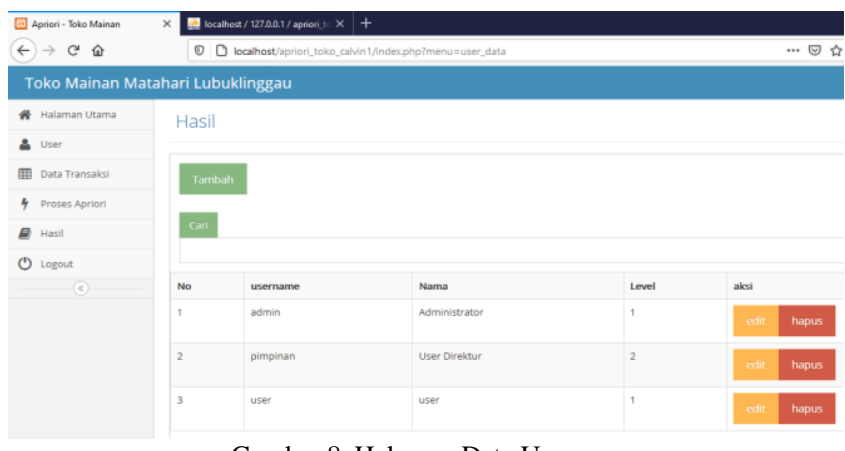

Gambar 8 Halaman Data User

\section{e. Halaman Input Data Transaksi}

Admin dapat menginputkan memilih data mana yang akan dipilih lewat tombol choose, kemudian klik tombol upload, maka data akan muncul dibawahnya. Data transaksi dapat diolah seperti melakukan penghapusan data setelah data yang dipilih tadi akan dibatalkan, dan pencarian data. Pada sistem ini pengguna yang memiliki hak akses yaitu admin. Adapun halaman input data transaksi tertera seperti gambar dibawah ini :

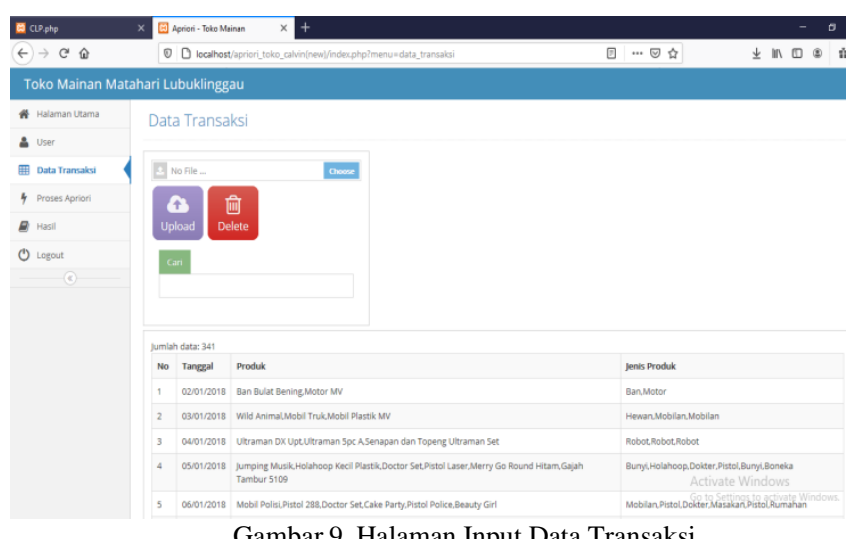

Gambar 9 Halaman Input Data Transaks 


\section{f. Halaman Proses Apriori}

Admin dapat menginputkan memilih rentang tanggal yang akan dipilih kemudian klik tombol search, maka data akan muncul dibawahnya. Kemudian masukkan minimal support dan minimal confidence. Pada sistem ini pengguna yang memiliki hak akses yaitu admin. Adapun halaman proses data apriori tertera seperti gambar dibawah ini :

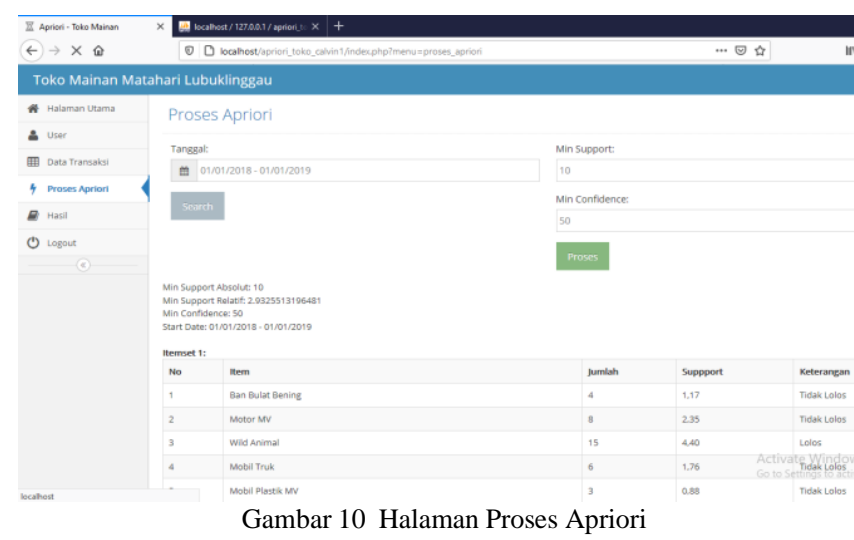

g. Halaman Data Hasil

Pada halaman data hasil berisi data-data proses apriori yang telah di input sebelumnya. Data hasil dapat diolah dapat melakukan pencarian data. Pada sistem ini pengguna yang memiliki hak akses yaitu admin dan dari pimpinan itu sendiri. Adapun halaman data hasil tertera seperti gambar dibawah ini :

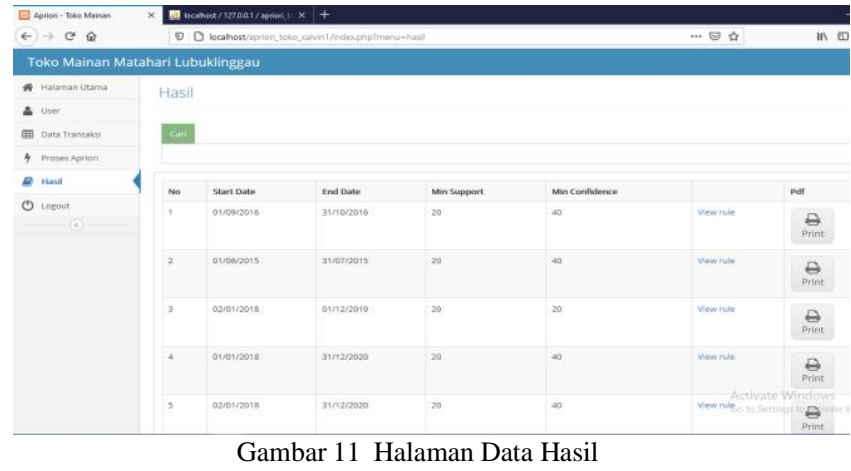

\section{h. Halaman Data View Rule}

Pada halaman data view rule berisi data-data proses apriori yang telah di input sebelumnya. Pada sistem ini pengguna yang memiliki hak akses yaitu admin dan dari pimpinan itu sendiri. Adapun halaman data hasil tertera seperti gambar dibawah ini :

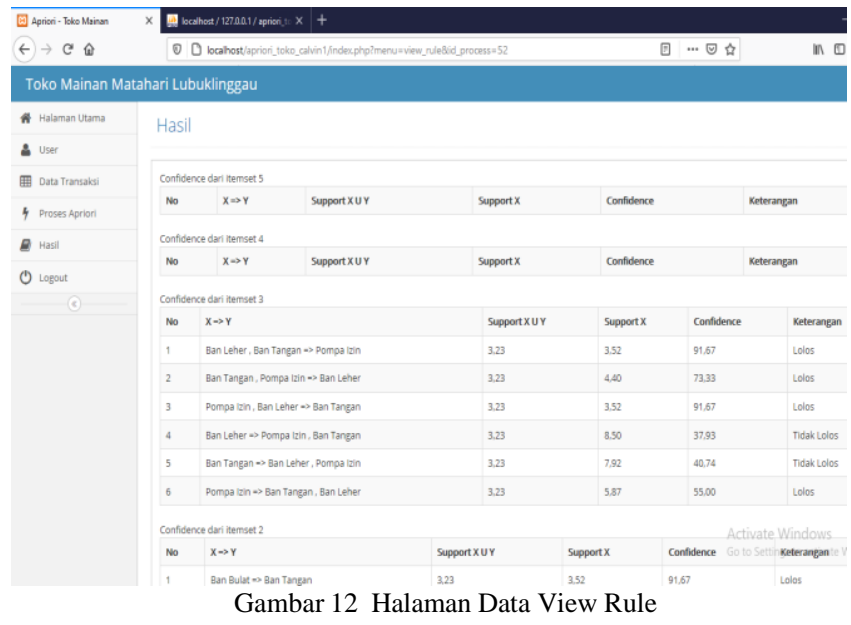

\section{i. Halaman Laporan Analisa}

Halaman laporan data analisa berisi data-data analisa yang sudah diinputkan sebelumnya, berdasarkan perhitungan di proses apriori. Adapun halaman laporan analisa tertera seperti gambar dibawah ini :

\begin{tabular}{|c|c|c|}
\hline \multicolumn{3}{|c|}{$\begin{array}{c}\text { Laporan Hasil Analiza } \\
\text { TOKO MATAHARI LUBCKLINGGAU }\end{array}$} \\
\hline No & Rule & Niliai Kepastian \\
\hline 1 & 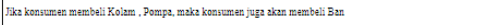 & 92,31 \\
\hline 2 & 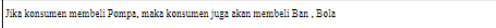 & 55.56 \\
\hline 3 & 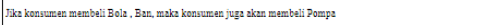 & 76,92 \\
\hline 4 & 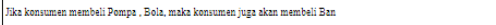 & 100,00 \\
\hline s & 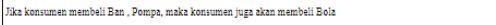 & 66,67 \\
\hline 6 & 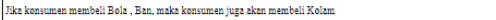 & 84,62 \\
\hline , & 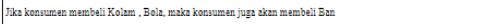 & 91,67 \\
\hline 8 & 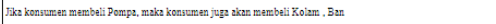 & 66,67 \\
\hline 9 & 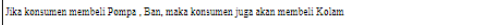 & 80,00 \\
\hline 10 & 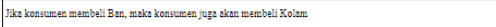 & 76,47 \\
\hline 11 & 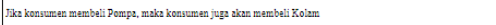 & 72.22 \\
\hline 12 & 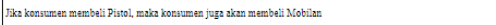 & 58,82 \\
\hline 13 & 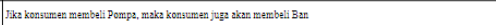 & 83,33 \\
\hline
\end{tabular}

\section{Kesimpulan dan Saran}

\subsection{Kesimpulan}

Dalam penulisan skripsi ini penulis telah menguraikan bagaimana perencanaan sistem dalam membangun " Implementasi Metode Apriori pada Data Mining untuk Pola Pembelian Barang pada Toko Matahari Kota Lubuklinggau". Adapun kesimpulan dari hasil skripsi ini adalah :

1) Dalam penelitian ini maka dihasilkan aplikasi data mining untuk pola pembelian barang pada Toko Matahari Kota Lubuklinggau. Dimana sistem ini dibuat untuk membantu pimpinan dalam meningkatkan keuntungan dan penyusunan produk.

2) Data mining pola pembelian barang memiliki dua hak akses yaitu admin dan dari pimpinan itu sendiri.

3) Aplikasi data mining ini dibentuk dengan menggunakan bahasa pemrograman php dan database mysql sebagai penampung datanya. 


\subsection{Saran}

Berdasarkan hasil penelitian dan kesimpulan yang telah diuraikan tentu saja masih banyak terdapat kekurangan, karena itu penulis berharap penelitian ini dapat dikembangkan lagi agar mendapatkan hasil yang maksimal. Berikut ini adalah beberapa saran yang penulis berikan untuk arah perkembangan selanjutnya:

1) Dalam penelitian selanjutnya diharapkan perancangan data mining pola pembelian barang dapat diterapkan pada kasus lain selain penjualan mainan.

2) Keamanan pada sistem data mining pola pembelian barang ini masih kurang dan perlu dilakukan pengembangan.

3) Pengembangan penelitian selanjutnya dapat diperdalam lagi dengan menggembangkan sistem menjadi online sehingga sistem dapat diakses dimana saja.

\section{Daftar Rujukan}

[1] Purnia, D. S. \& Warnilah, A. I., 2017. Implementasi Data Mining Pada Penjualan Kacamata Menggunakan Algoritma Apriori. IJCIT (Indonesian Journal on Computer and Information Technology), 2(2), pp. 31-39.

[2] Sari, R., 2018. IMPLEMENTASI ALGORITMA APRIORI PADA DATA MINING UNTUK POLA PEMINJAMAN BUKU DI PERPUSTAKAAN UIN RADEN FATAH PALEMBANG, Palembang: UNIVERSITAS ISLAM NEGERI RADEN FATAH.

[3] Sikumbang, E. D., 2018. Penerapan Data Mining Penjualan Sepatu. Komputerisasi Akuntansi, 4(1), pp. 156161.

[4] Syahdan, S. A. \& Sindar, A., 2018. Data Mining Penjualan Produk Dengan Metode Apriori. Jurnal Nasional Komputasi \& Teknologi Informasi, 1(2), pp. 56-63.

[5] Bilqisth, S. C. \& Astuti, S., 2015. ANALISIS POLA PEMBELIAN KONSUMEN DENGAN ALGORITMA APRIORI PADA INDOMARET INDRAPRASTA SEMARANG. pp. 1-10.

[6] Metisen, B. M. \& Sari, H. L., 2015. ANALISIS CLUSTERING MENGGUNAKAN METODE KMEANS. Jurnal Media Infotama, 11(2), pp. 110-118.

[7] Widodo, M., 2016. Data Mining Penjualan Barang Bengkel Menggunakan Metode Apriori. Jurnal Media Infotama, 11(2), pp. 54-60.

[8] Munthe, R., Santosa, P. I. \& Ferdiana, R., 2015. Usulan Metode Evaluasi User Acceptance Testing (UAT) dalam Pengembangan Perangkat Lunak. Prosiding Seminar Nasional Pendidikan Teknik Informatika, pp. 159-162.

[9] Firman, A., Wowor, H. F. \& Najoan, X., 2016. Sistem Informasi Perpustakaan Online Berbasis Web. E-journal Teknik Elektro dan Komputer, 5(2), pp. 29-36.

[10] Mulyono, H., 2016. SISTEM INFORMASI PENJUALAN ALAT-ALAT MUSIK PADA TOKO GALERI MUSIK VIONA LUBUKLINGGAU BERBASIS WEB. JTI, 8(2), pp. 38-48. 